\title{
MEASURED AND CALCULATED HEATING AND DOSE RATES FOR THE HFIR HB4 BEAM TUBE AND COLD SOURCE
}

\section{March 2009}

\author{
Prepared by \\ C. O. Slater \\ R. T. Primm III \\ D. A. Pinkston \\ D. H. Cook \\ D. L. Selby \\ P. D. Ferguson \\ J. A. Bucholz \\ E. Popov
}

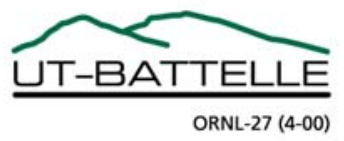




\section{DOCUMENT AVAILABILITY}

Reports produced after January 1, 1996, are generally available free via the U.S. Department of Energy (DOE) Information Bridge.

Web site http://www.osti.gov/bridge

Reports produced before January 1, 1996, may be purchased by members of the public from the following source.

National Technical Information Service

5285 Port Royal Road

Springfield, VA 22161

Telephone 703-605-6000 (1-800-553-6847)

TDD 703-487-4639

Fax 703-605-6900

E-mail info@ntis.gov

Web site http://www.ntis.gov/support/ordernowabout.htm

Reports are available to DOE employees, DOE contractors, Energy Technology Data Exchange (ETDE) representatives, and International Nuclear Information System (INIS) representatives from the following source.

Office of Scientific and Technical Information

P.O. Box 62

Oak Ridge, TN 37831

Telephone 865-576-8401

Fax 865-576-5728

E-mail reports@osti.gov

Web site http://www.osti.gov/contact.html

This report was prepared as an account of work sponsored by an agency of the United States Government. Neither the United States Government nor any agency thereof, nor any of their employees, makes any warranty, express or implied, or assumes any legal liability or responsibility for the accuracy, completeness, or usefulness of any information, apparatus, product, or process disclosed, or represents that its use would not infringe privately owned rights. Reference herein to any specific commercial product, process, or service by trade name, trademark, manufacturer, or otherwise, does not necessarily constitute or imply its endorsement, recommendation, or favoring by the United States Government or any agency thereof. The views and opinions of authors expressed herein do not necessarily state or reflect those of the United States Government or any agency thereof. 
Nuclear Science and Technology Division

Research Reactors Division

Neutron Facilities Development Division

\title{
MEASURED AND CALCULATED HEATING AND DOSE RATES FOR THE HFIR HB4 BEAM TUBE AND COLD SOURCE
}

\author{
C. O. Slater \\ R. T. Primm III \\ D. A. Pinkston \\ D. H. Cook \\ D. L. Selby \\ P. D. Ferguson \\ J. A. Bucholz \\ E. Popov
}

Date Published: March 2009

\author{
Prepared by \\ OAK RIDGE NATIONAL LABORATORY \\ P.O. Box 2008 \\ Oak Ridge, Tennessee 37831-6283 \\ managed by \\ UT-Battelle, LLC \\ for the \\ U.S. DEPARTMENT OF ENERGY \\ under contract DE-AC05-00OR22725
}

\footnotetext{
${ }^{*}$ Formerly of the Nuclear Science and Technology Division, Oak Ridge National Laboratory.
} 



\section{CONTENTS}

Page

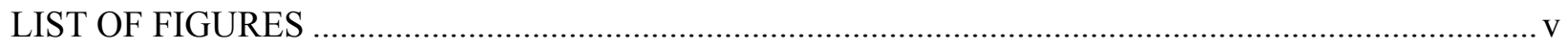

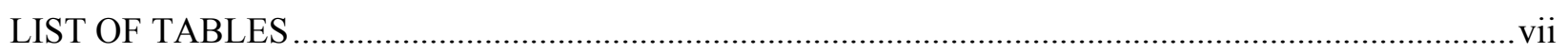

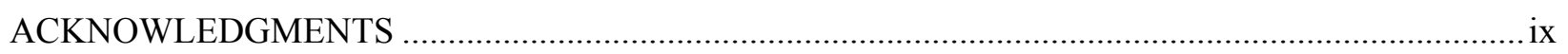

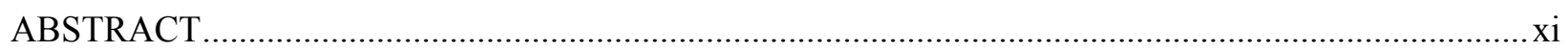

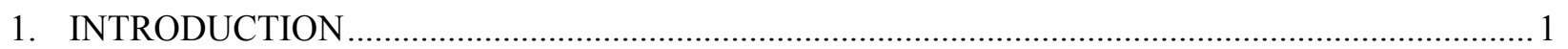

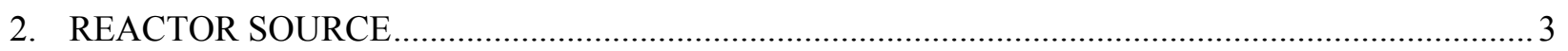

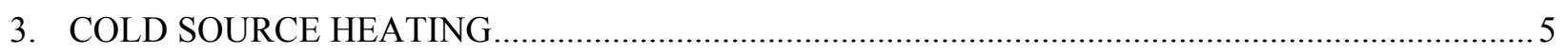

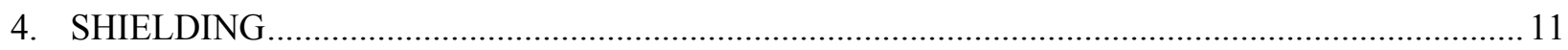

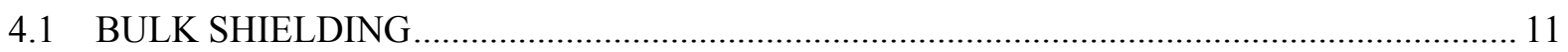

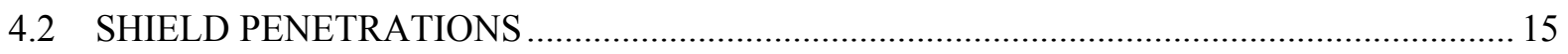

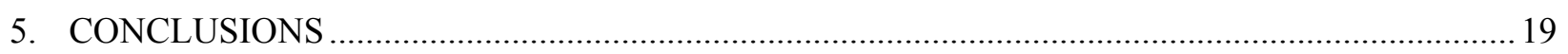

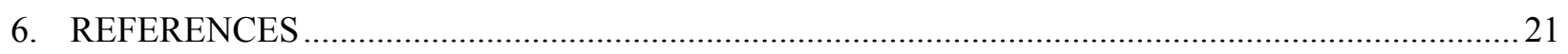





\section{LIST OF FIGURES}

Figure

$1 \quad$ Plan view of the High Flux Isotope Reactor at the core midplane ........................................ 1

2 Cutaway view of the fuel element for the High Flux Isotope Reactor ..................................... 4

3 Comparison of calculated and measured nuclear heating for the HFIR HB4 cold source ........... 7

4 Plan view of the MCNP geometry for the HFIR HB4 isolated beam tube model at the

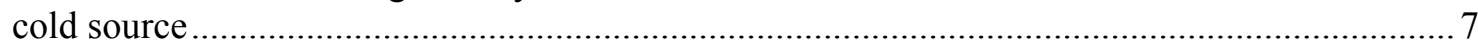

5 Elevation view of the MCNP geometry for the HFIR HB4 isolated beam tube model

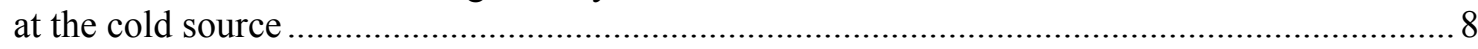

6 Three-dimensional heating distribution for the HFIR HB4 cold source vessel........................ 10

7 Plan view of the HFIR HB4 beam tube shielding, experiment stations, and structures ............. 12

8 Plan view of the HFIR HB4 beam tube shielding and components within the beam room ....... 13

9 Plan view of the MCNP geometry for the hydrogen transfer line in the east shield wall........... 16

10 Elevation view of the MCNP geometry for the hydrogen transfer line in the east shield wall .. 16 



\section{LIST OF TABLES}

Table

Page

1 Comparison of BOC heating rates in the cold source $\mathrm{LH}_{2}$ as calculated using the full HFIR model and the isolated beam tube model (coarse-group source distributions)

2 Comparison of BOC heating rates in the cold source $\mathrm{LH}_{2}$ as calculated using the full HFIR model and the isolated beam tube model (fine-group source distributions for all variables except angle)

3 Comparison of BOC heating rates in the cold source $\mathrm{LH}_{2}$ as calculated using the full HFIR model and the isolated beam tube model (fine-group source distributions).

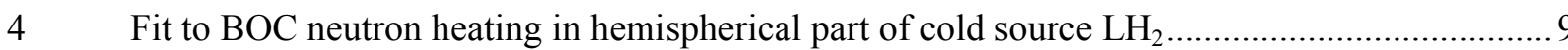

5 Comparison of calculated and measured neutron and photon contact dose rates

(in millirems per hour) for the HFIR HB4 shield tunnel 



\section{ACKNOWLEDGMENTS}

The authors thank D. E. Peplow and E. D. Blakeman of Oak Ridge National Laboratory (ORNL) for their technical review of the report and D. J. Weaver of ORNL for formatting the manuscript. Funding for the work was provided by the U.S. Department of Energy Office of Science. 



\begin{abstract}
The High Flux Isotope Reactor at the Oak Ridge National Laboratory was upgraded to install a cold source in horizontal beam tube number 4 . Calculations were performed and measurements were made to determine nuclear heating within the cold source and dose rates within and outside a shield tunnel surrounding the beam tube. This report briefly describes the calculations and presents comparisons of the measured and calculated results. Some calculated dose rates are in fair-to-good agreement with the measured results, while others, particularly those at the shield interfaces, differ greatly from the measured results. The calculated cold source nuclear heating is in good agreement with the measured heating.
\end{abstract}





\section{INTRODUCTION}

The Oak Ridge National Laboratory's High Flux Isotope Reactor (HFIR) was initially put into service in 1966. It was designed with high thermal-neutron-flux regions to produce radioisotopes for medical and industrial applications. Beam tubes were also installed so that scientists could perform neutron scattering studies. A plan view of the reactor is shown in Fig. 1. To enhance the scientific capabilities of the reactor, staff recently (1995-2007) upgraded the facility by enlarging beam tubes and adding a cold source to one beam tube. The cold source consists of an aluminum vessel containing liquid hydrogen cooled to a temperature near $20 \mathrm{~K}$. The thermal-neutron flux $(\mathrm{E}<0.104 \mathrm{eV})$ is increased more than an order of magnitude by the cold source. New neutron guides and detectors were designed and installed, and calculational analyses were performed to help guide the design process. Of concern were cooling requirements for the cold source (reasonably accurate heating rates were needed) and shielding requirements for the beam tube during operating and shutdown conditions. Calculations for the HFIR horizontal beam tube number 4 (HB4) are described, and comparisons of measured and calculated results are presented.

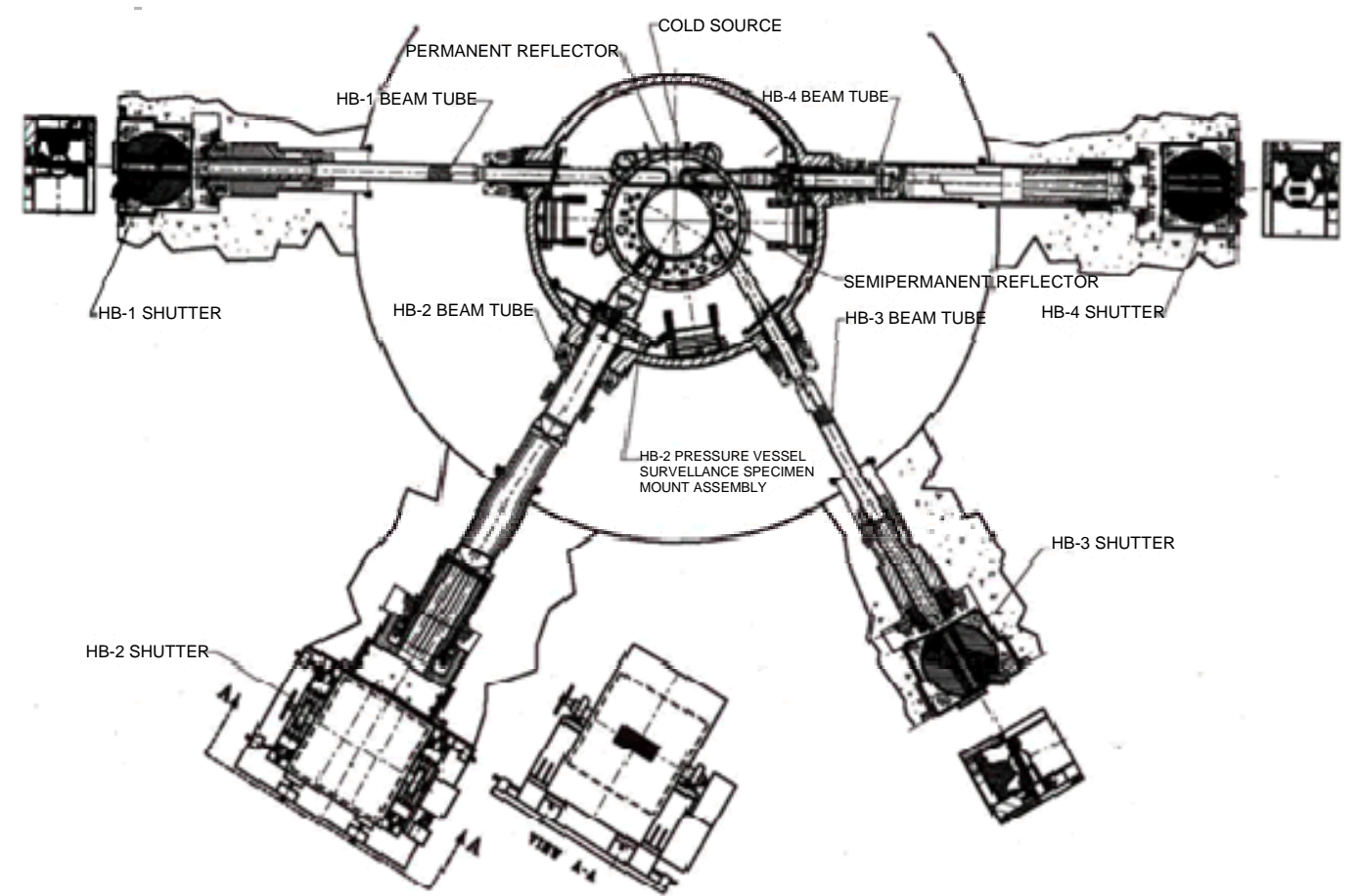

Fig. 1. Plan view of the High Flux Isotope Reactor at the core midplane.

The HFIR HB4 is a tangential beam tube that abuts and is parallel to horizontal beam tube number 1 (HB1). Beam tube HB4 begins in the beryllium reflector and passes through the water pool, the reactor vessel, and the concrete biological shield. The cold source is located near the origin of the beam tube. At the end of the beam tube, four glass guides are installed to direct the cold neutrons to the various experiments. The guides pass through the beam room and a transition building prior to their entry into the guide hall. A shield tunnel with sufficient room for maintenance and component placement surrounds the guides as they pass through the beam room and transition building. Two thick concrete bulkheads help to limit the neutron source in the guide hall to that which travels within the beam channels. A geometry model of the shield tunnel from the HB4 shutter to the guide hall was developed and modified as needed to reflect changes in design or to accommodate investigative studies. This geometry model was used with the MCNP Monte Carlo code. ${ }^{1}$ 



\section{REACTOR SOURCE}

A major part of the heating and shielding calculations is the characterization of the reactor source. The source emanates from a highly enriched concentric fuel element, the reactor core (Fig. 2), operating at critical conditions. Concentric control cylinders around the fuel element are moved during the $\sim 25$-day cycle to maintain criticality and power level. Reactor calculations were performed for two states of the reactor core: (1) the state when the fuel is fresh and the control cylinders are at their initial positions (beginning-of-cycle, or BOC, conditions) and (2) the state near the time the fuel is to be discharged and the control cylinders are at their maximum positions (end-of-cycle, or EOC, conditions). The material compositions of the homogenized fresh-fuel regions (BOC) were determined from the specifications given for the manufactured fuel and the volumes occupied by the fuel, cladding, and coolant. For the EOC fuel compositions, the fission distribution within the core was calculated using diffusion theory with codes from the VENTURE modular code system ${ }^{2}$ and the BOC fuel compositions. Codes from the VENTURE system were then used to perform a burnup analysis of the fuel during the typical reactor cycle. Data from this analysis were used to determine homogenized fuel compositions for EOC conditions. Radiation quantities calculated for the BOC and EOC conditions are thought to be lower and upper bounds, respectively, for the same quantities calculated at other times during the cycle.

Additionally, photon release from decaying fission products was calculated. A representative spectrum was calculated for the cycle, and the decay-photon production was incorporated into a special ${ }^{235} \mathrm{U}$ cross-section array. These cross sections were then used in the MCNP5 $\mathrm{k}_{\text {eff }}$ calculations. The annular fuel regions are $5.4572 \mathrm{~cm}$ thick (2.15 in.) by $50.8 \mathrm{~cm}$ high (20.0 in.) in the inner region and $5.8039 \mathrm{~cm}$ thick ( 2.285 in.) by $50.8 \mathrm{~cm}$ high (20.0 in.) in the outer region. The inner core was subdivided into eight radial by seven axial zones, while the outer core was subdivided into nine radial by seven axial zones. There are 17 material compositions for the BOC core ( 8 for the inner core and 9 for the outer core) and 30 for the EOC core (12 for the inner core and 18 for the outer core). For the BOC core, there was only radial variation of the materials, with a different material in each radial band. The EOC core was coarsely subdivided into $18 \mathrm{RZ}$ superzones ( $3 \mathrm{Z}$ by $6 \mathrm{R}$ ), and materials were assigned to all zones within a given superzone. RZ superzones contained 2, 3, 4, 6, or 9 zones.

Although the discrete fission distributions from the VENTURE diffusion calculations could have been used, calculations in the reactor core were performed using versions of the MCNP code. The option of a $\mathrm{k}_{\text {eff }}$ calculation is easier to implement in MCNP than is the option of a fixed-source calculation using a discrete spatial fission distribution from VENTURE along with the neutron and photon energy spectra from fission. With the $\mathrm{k}_{\text {eff }}$ calculation, only a single MCNP calculation is needed to determine neutron and photon fluxes within the reactor system. Therefore, two $\mathrm{k}_{\text {eff }}$ calculations (BOC and EOC) were performed using the material compositions from the diffusion theory calculations. For these cases, tallies from the calculations determined heating rates or dose rates in regions of interest, and the calculations also provided localized sources that could be used to analyze a much smaller portion of the full HFIR model. For the shielding calculations, equivalent point sources developed by Bucholz $z^{3}$ were used to analyze the beam tube model. For the heating calculations, MCNP5 leakages across cylindrical surfaces surrounding the HB4 beam tube were binned over energy, space, and direction and then incorporated into the MCNP5 calculations via a user-written "SOURCE" subroutine. The data file was ASCII formatted so that it could be used on any computer on which MCNP5 runs. 


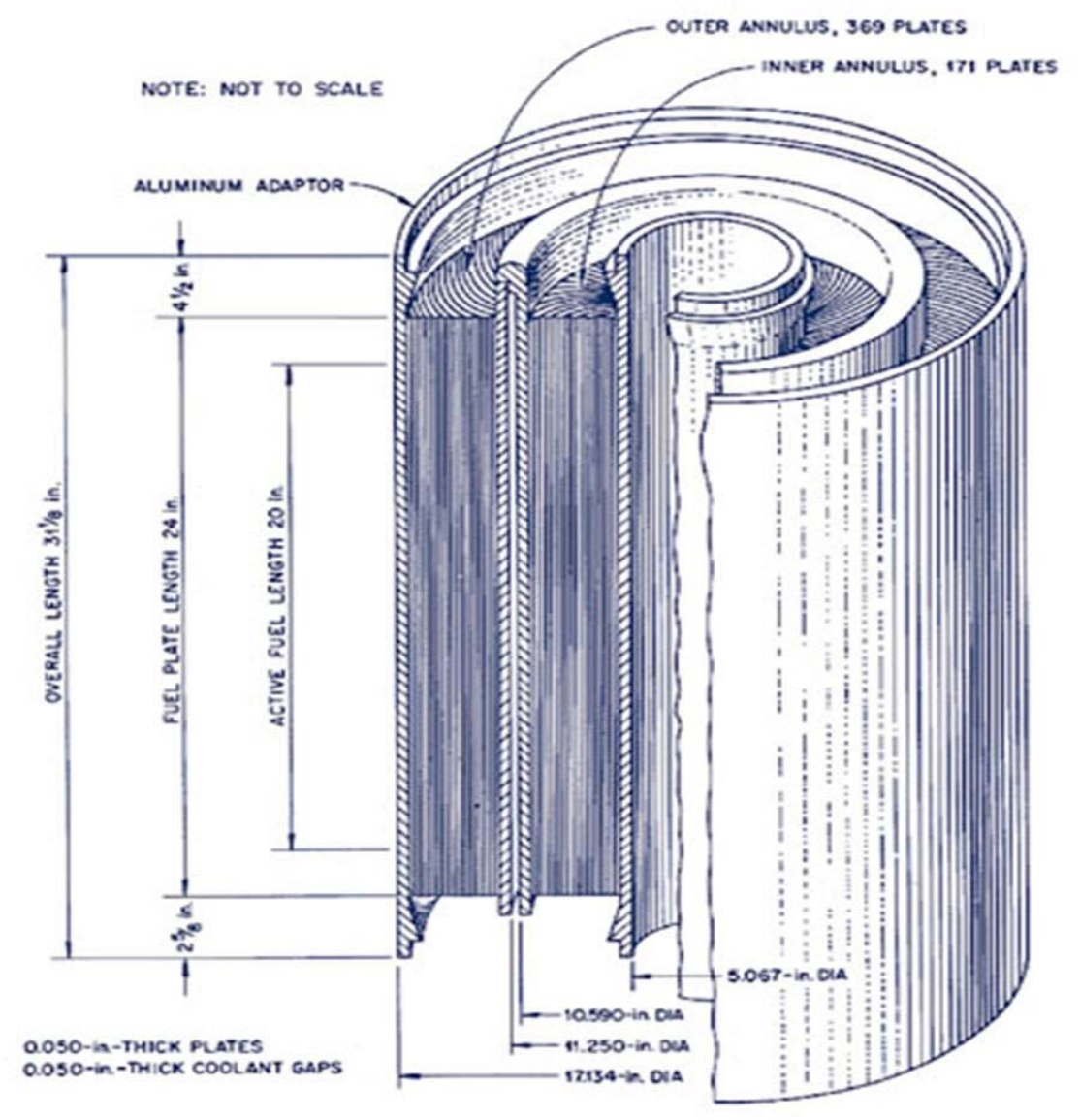

Fig. 2. Cutaway view of the fuel element for the High Flux Isotope Reactor. 


\section{COLD SOURCE HEATING}

During reactor operation, radiation will deposit heat in the cold source moderator and vessel. This heat, along with any mechanically induced heat, must be removed if the moderator temperature is to be kept within the optimum range. Thus, a reasonably accurate calculation of the cold source heating is needed. This heating impacts the required heat-removal capability and the reactor power level if the hot-spot temperature limit will be exceeded at a certain power level. Initial heating calculations used the full HFIR model and appropriate numbers of histories to calculate heating rates within the cold source vessel and the $\mathrm{LH}_{2}$ moderator. A special aluminum cross-section array was used to account for photon production due to neutron capture in ${ }^{27} \mathrm{Al}$ and the subsequent decay of ${ }^{28} \mathrm{Al}$. Special cross sections for orthohydrogen and parahydrogen at $20 \mathrm{~K}$ were also included. Heating was calculated using (1) the built-in heating tallies, (2) a volume tally using cross sections from the MCNP5 dosimetry library, or (3) a volume tally for which the calculated activities were folded with the average energy release per interaction (such as the $1.247-\mathrm{MeV}$ beta particle release from $\left.{ }^{28} \mathrm{Al}\right)$.

The cold source moderator and vessel were subdivided into cells, and heating was calculated in those cells so that a detailed distribution of heating within the cold source could be determined. Initially, the cold source moderator and vessel were subdivided into 30 nonvoid cells. The regions were subdivided along the axis of the beam tube and by a vertical plane parallel to and through the center of the tube. This number of cells was not adequate for supplying detailed heating distributions to the heat transfer code that would be used to calculate temperatures in the cold source aluminum vessel. Thus, an isolated beam tube model was developed for the purpose of performing faster calculations for beam tube models having finer subdivisions of the cold source. The isolated beam tube model having the same cold source cells as the full model was first calculated to determine if the results obtained agreed closely with those obtained from the full-model calculations. The results agreed closely and gave assurance that the user-written "SOURCE" subroutine was working properly. Some comparisons are shown in Tables 1-3. Table 1 shows a comparison of the full-model results with those from an isolated beam tube calculation that used source distributions having a coarse-energy structure for all distributions; Table 2 shows a comparison of the full-model results with those from an isolated beam tube calculation that used source distributions having a fine-energy structure for all except the angular distribution; and Table 3 shows a comparison of the full-model results with those from an isolated beam tube calculation that used source distributions having a fine-energy structure for all distributions. The distributions having the fine-energy structure gave better agreement than the one having a coarse-energy structure for all distributions. However, it appears that the calculation using the fine-energy structure for all distributions except the angular distribution gave slightly better agreement than the calculation that used the fine-energy structure for all distributions.

Figure 3 shows a comparison of the calculated and measured heat load for the cold source. The heating rates for cells in the $\mathrm{LH}_{2}$ and the aluminum vessel were multiplied by the masses (in grams) of the cells and summed to obtain the calculated total heat loads. The agreement with the EOC calculations is very good, while the BOC results are lower than the measured results. One would expect better agreement with the EOC calculation because the fuel compositions quickly approach EOC conditions after fission begins. A true BOC measurement is not possible since fissioning changes the fuel compositions in a shorter time span than that required for the measurements. Significant heating of the cold source (and thus significant fissioning and changes in fuel composition) is required before an accurate measurement of the heating can be made. 
Table 1. Comparison of BOC heating rates in the cold source $\mathrm{LH}_{2}$ as calculated using the full HFIR model and the isolated beam tube model

(coarse-group source distributions)

\begin{tabular}{cccccc}
\hline \multirow{2}{*}{ Cell } & \multicolumn{3}{c}{ Heating rate (W/g) } \\
\cline { 2 - 3 } \cline { 5 - 6 } & \multicolumn{3}{c}{ Neutron } & \multicolumn{3}{c}{ Photon } \\
\cline { 2 - 3 } \cline { 5 - 6 } & Full model & Tube model (ratio) & & Full model & Tube model (ratio) \\
\hline 86011 & 10.209 & $10.649(1.043)$ & & 5.8636 & $6.1801(1.054)$ \\
86012 & 6.3805 & $6.6763(1.046)$ & & 4.9339 & $5.1636(1.047)$ \\
86051 & 10.104 & $10.577(1.047)$ & & 5.5573 & $5.8859(1.059)$ \\
86051 & 5.8291 & $6.1836(1.061)$ & & 4.4705 & $4.7219(1.056)$ \\
86091 & 8.3470 & $8.8288(1.058)$ & & 4.7701 & $5.0103(1.050)$ \\
86092 & 5.2021 & $5.3302(1.025)$ & & 3.6736 & $3.8689(1.053)$ \\
86135 & 4.7457 & $4.8900(1.030)$ & & 3.4698 & $3.7506(1.081)$ \\
86136 & 3.6620 & $3.6759(1.004)$ & & 2.9008 & $3.0237(1.042)$ \\
86137 & 0.23105 & $0.24748(1.071)$ & & 0.34826 & $0.35244(1.012)$ \\
86138 & 0.23893 & $0.26939(1.127)$ & & 0.33543 & $0.36044(1.075)$ \\
\hline
\end{tabular}

Table 2. Comparison of BOC heating rates in the cold source $\mathrm{LH}_{2}$ as calculated using the full HFIR model and the isolated beam tube model

(fine-group source distributions for all variables except angle)

\begin{tabular}{cccccc}
\hline \multirow{2}{*}{ Cell } & \multicolumn{3}{c}{ Heating rate (W/g) } \\
\cline { 2 - 3 } \cline { 2 - 3 } \cline { 5 - 6 } & Full model & Tube model (ratio) & & Full model & Tube model (ratio) \\
\hline 86011 & 10.209 & $10.218(1.001)$ & & 5.8636 & $5.9362(1.012)$ \\
86012 & 6.3805 & $6.4478(1.011)$ & & 4.9339 & $5.0185(1.017)$ \\
86051 & 10.104 & $10.274(1.017)$ & & 5.5573 & $5.6448(1.016)$ \\
86051 & 5.8291 & $5.9410(1.019)$ & & 4.4705 & $4.5998(1.029)$ \\
86091 & 8.3470 & $8.5561(1.025)$ & & 4.7701 & $4.8446(1.016)$ \\
86092 & 5.2021 & $5.3921(1.037)$ & & 3.6736 & $3.7405(1.018)$ \\
86135 & 4.7457 & $5.3263(1.122)$ & & 3.4698 & $3.5658(1.028)$ \\
86136 & 3.6620 & $3.7333(1.019)$ & & 2.9008 & $2.8930(0.997)$ \\
86137 & 0.23105 & $0.23050(0.998)$ & & 0.34826 & $0.34131(0.980)$ \\
86138 & 0.23893 & $0.23895(1.000)$ & & 0.33543 & $0.35014(1.044)$ \\
\hline
\end{tabular}

Table 3. Comparison of BOC heating rates in the cold source $\mathrm{LH}_{2}$ as calculated using the full HFIR model and the isolated beam tube model

(fine-group source distributions)

\begin{tabular}{cccccc}
\hline \multirow{2}{*}{ Cell } & \multicolumn{3}{c}{ Heating rate (W/g) } \\
\cline { 2 - 3 } \cline { 5 - 6 } & \multicolumn{3}{c}{ Neutron } & \multicolumn{2}{c}{ Photon } \\
\cline { 2 - 3 } \cline { 5 - 6 } & Full model & Tube model (ratio) & & Full model & Tube model (ratio) \\
\hline 86011 & 10.209 & $10.429(1.022)$ & & 5.8636 & $5.9315(1.012)$ \\
86012 & 6.3805 & $6.5220(1.022)$ & & 4.9339 & $4.9928(1.012)$ \\
86051 & 10.104 & $10.210(1.010)$ & & 5.5573 & $5.6334(1.014)$ \\
86051 & 5.8291 & $6.0687(1.041)$ & & 4.4705 & $4.5579(1.020)$ \\
86091 & 8.3470 & $8.4732(1.015)$ & & 4.7701 & $4.8154(1.009)$ \\
86092 & 5.2021 & $5.4759(1.053)$ & & 3.6736 & $3.7408(1.018)$ \\
86135 & 4.7457 & $5.0181(1.057)$ & & 3.4698 & $3.5956(1.036)$ \\
86136 & 3.6620 & $4.0214(1.098)$ & & 2.9008 & $2.9438(1.015)$ \\
86137 & 0.23105 & $0.22486(0.973)$ & & 0.34826 & $0.34526(0.991)$ \\
86138 & 0.23893 & $0.25381(1.062)$ & 0.33543 & $0.34987(1.043)$ \\
\hline
\end{tabular}




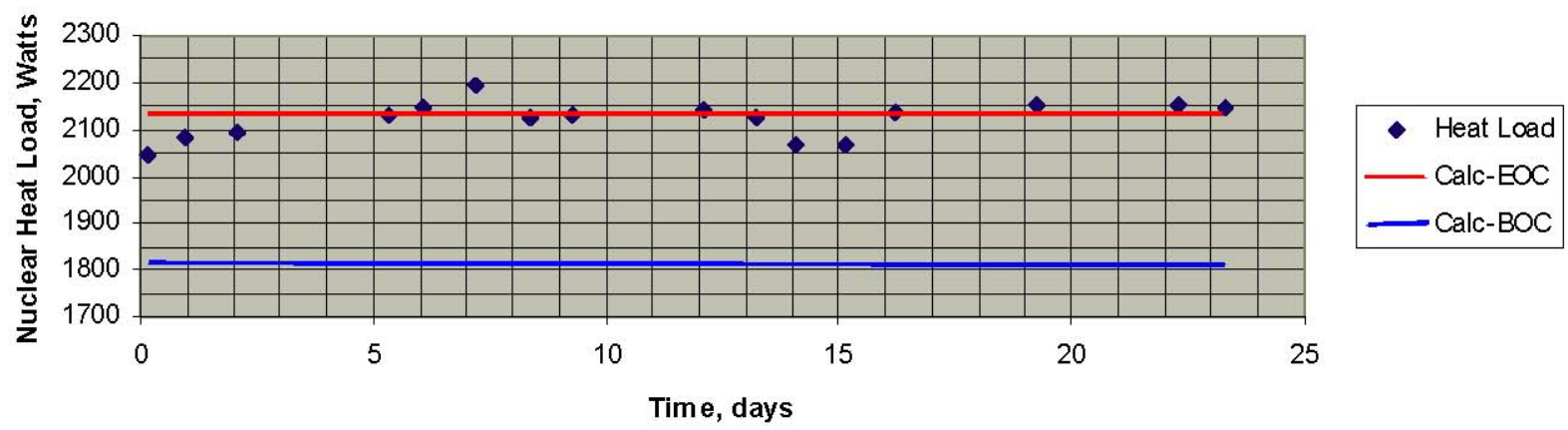

Fig. 3. Comparison of calculated and measured nuclear heating for the HFIR HB4 cold source.

As previously noted, the cold source regions needed to be finely subdivided if detailed heating distributions were to be obtained from the tallied heating rates. Therefore, the cold source moderator and vessel were finely subdivided axially, radially, and azimuthally (482 cells), and heating rates were calculated for the BOC and EOC cores. Figures 4 and 5, respectively, show plan and elevation views of the MCNP geometry model around the cold source. To enable the generation of detailed heating distributions for any spatial meshing of the cold source moderator and vessel, we developed analytical expressions for several regions of the cold source moderator and vessel as functions of axial positions, radius (if the region were thick enough), and azimuth, as well as by type of heating (neutron, photon, beta, and total). These expressions could be easily programmed into a computer code.

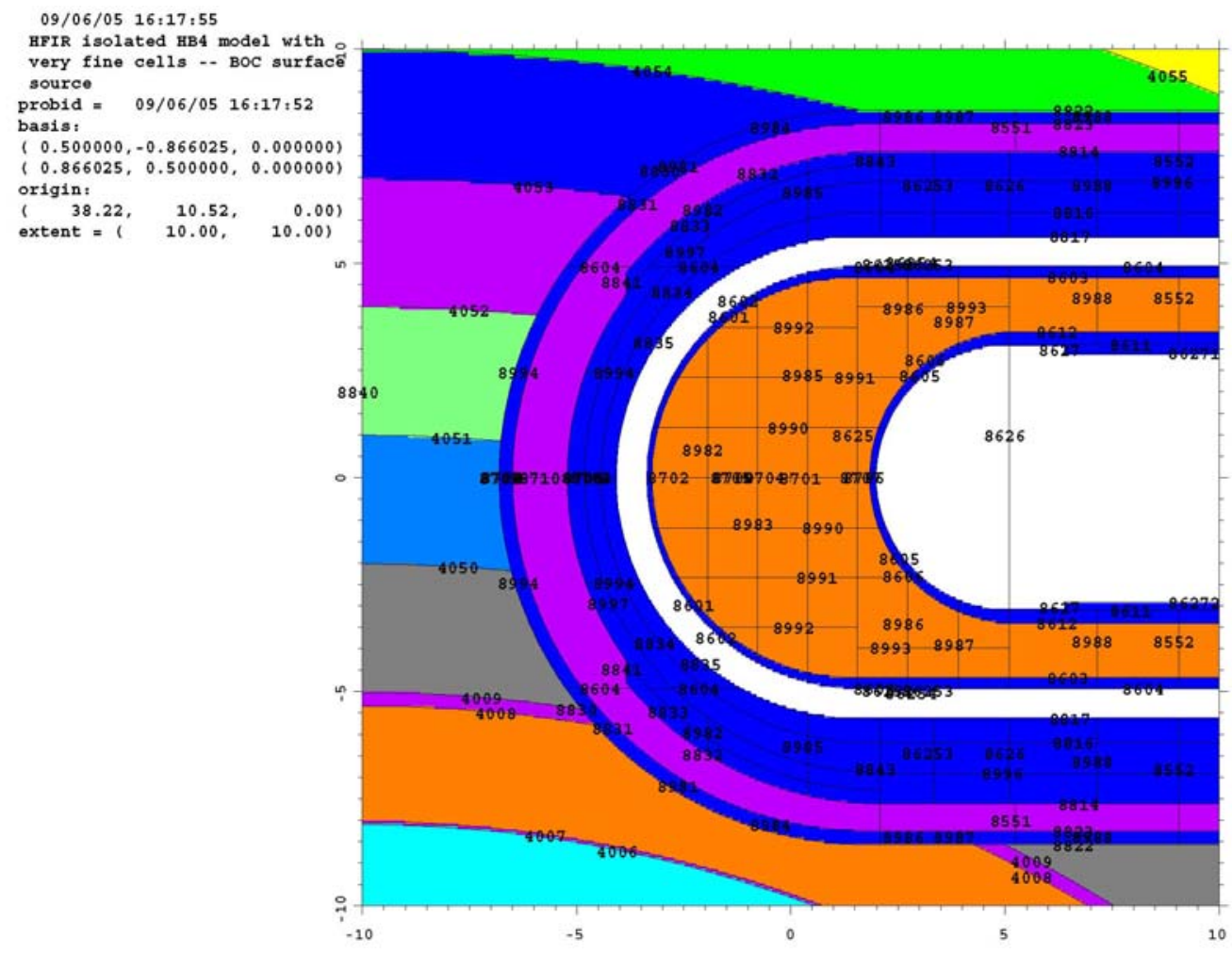

Fig. 4. Plan view of the MCNP geometry for the HFIR HB4 isolated beam tube model at the cold source. The numbers on the figure are the MCNP surface labels. 


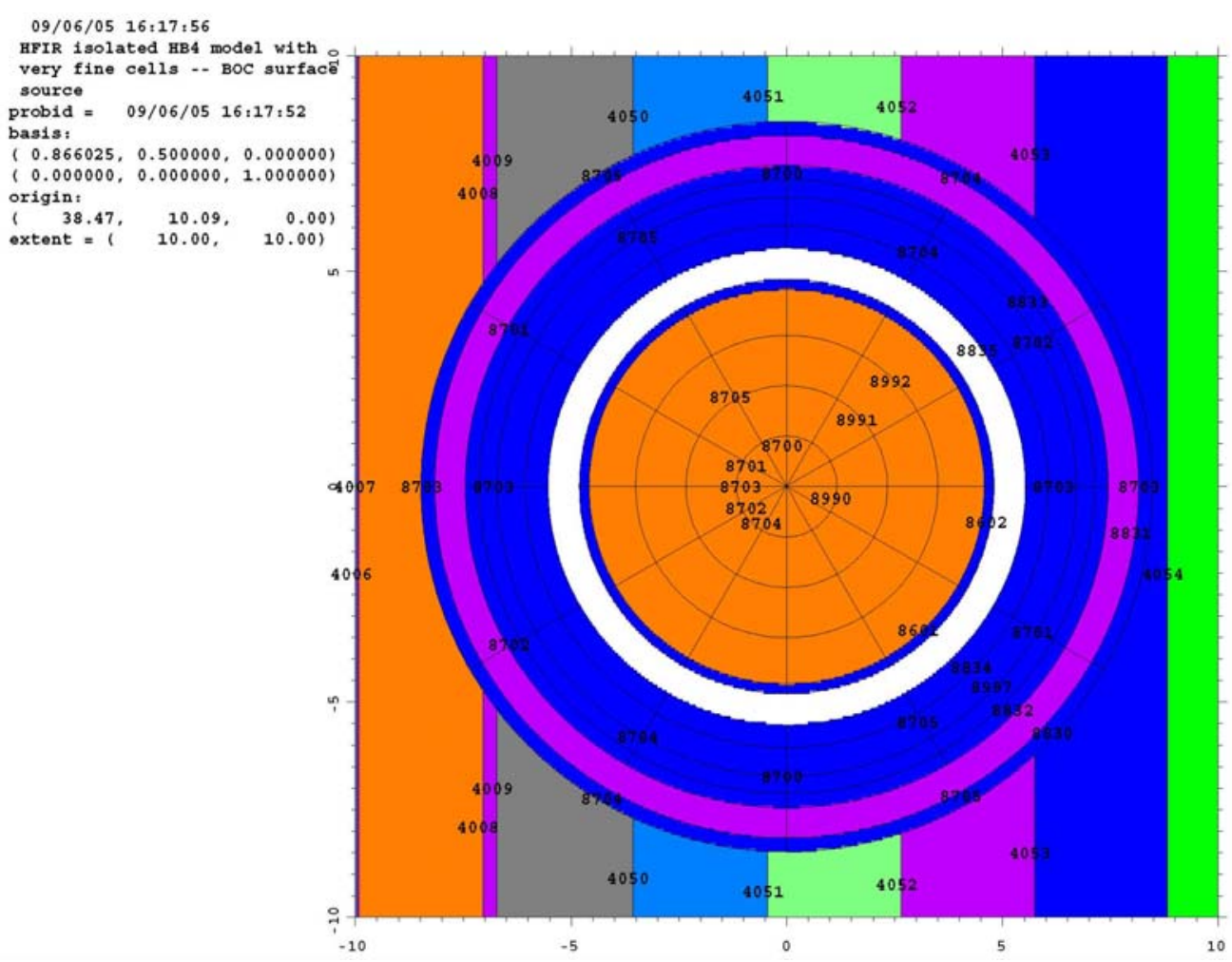

Fig. 5. Elevation view of the MCNP geometry for the HFIR HB4 isolated beam tube model at the cold source. The numbers on the figure are the MCNP surface labels.

Table 4 shows an example of MCNP5-calculated total heating over a region (the hemispherical portion of the $\mathrm{LH}_{2}$ moderator), the heating values calculated using the fitted analytical expression, and the percent difference between the calculated and fitted values. The MCNP5-calculated values were assumed to occur at the centers of the fine-mesh regions (centroids). The regions are small enough that small deviations of the specified points from the true centroids should not result in large errors in either the fitting function coefficients or the heating values calculated using the fitting functions. Figure 6 shows a three-dimensional plot of the surface heating (in watts per cubic meter) for the cold source vessel. Figure 6 shows that the maximum heating occurs on the core side of the tube and at the axial midplane of the tube. The temperature distribution for the vessel was calculated by a thermal-hydraulics code using heating-rate distributions based on the fitting functions derived from the MCNP-calculated heating data. $^{4,5}$ The calculated maximum temperature (hotspot) is $42.3 \mathrm{~K}$ and it occurs on the top of the vessel near the base of the hemispheral portion of the vessel. The allowable hotspot temperature is $150^{\circ} \mathrm{C}$ or about $423 \mathrm{~K}$. The calculated maximum temperature is well below the allowable temperature. Thus, the cold source vessel temperature is not a limiting factor for the reactor power level. 
Table 4. Fit to BOC neutron heating in hemispherical part of cold source $\mathbf{L H}_{2}$

\begin{tabular}{|c|c|c|c|c|c|c|}
\hline $\mathbf{i}$ & Cell & $\begin{array}{l}\text { Radius } \\
\text { (cm) }\end{array}$ & $\begin{array}{c}\text { Angle } \\
\text { (rad) }\end{array}$ & $\begin{array}{c}\text { Input } \\
\text { heating } \\
\text { (W/g) }\end{array}$ & $\begin{array}{c}\text { Fitted } \\
\text { heating } \\
\text { (W/g) }\end{array}$ & $\begin{array}{c}\text { Difference } \\
(\%)\end{array}$ \\
\hline 1 & 95001 & $2.571980 \mathrm{E}+00$ & $2.617993 \mathrm{E}-01$ & $6.186870 \mathrm{E}+00$ & $6.176665 \mathrm{E}+00$ & -0.1649 \\
\hline 2 & 95002 & $2.571980 \mathrm{E}+00$ & $7.853980 \mathrm{E}-01$ & $6.373170 \mathrm{E}+00$ & $6.524991 \mathrm{E}+00$ & 2.3822 \\
\hline 3 & 95003 & $2.571980 \mathrm{E}+00$ & $1.308997 \mathrm{E}+00$ & $7.290390 \mathrm{E}+00$ & $7.212481 \mathrm{E}+00$ & -1.0686 \\
\hline 4 & 95004 & $2.571980 \mathrm{E}+00$ & $1.832595 \mathrm{E}+00$ & $8.189410 \mathrm{E}+00$ & $8.209697 \mathrm{E}+00$ & 0.2477 \\
\hline 5 & 95005 & $2.571980 \mathrm{E}+00$ & $2.356194 \mathrm{E}+00$ & $9.346170 \mathrm{E}+00$ & $9.296213 \mathrm{E}+00$ & -0.5345 \\
\hline 6 & 95006 & $2.571980 \mathrm{E}+00$ & $2.879793 \mathrm{E}+00$ & $9.926390 \mathrm{E}+00$ & $1.003867 \mathrm{E}+01$ & 1.1311 \\
\hline 7 & 95007 & $2.571980 \mathrm{E}+00$ & $3.403392 \mathrm{E}+00$ & $9.967950 \mathrm{E}+00$ & $1.003973 \mathrm{E}+01$ & 0.7202 \\
\hline 8 & 95008 & $2.571980 \mathrm{E}+00$ & $3.926991 \mathrm{E}+00$ & $9.370940 \mathrm{E}+00$ & $9.266374 \mathrm{E}+00$ & -1.1159 \\
\hline 9 & 95009 & $2.571980 \mathrm{E}+00$ & $4.450589 \mathrm{E}+00$ & $8.108360 \mathrm{E}+00$ & $8.089997 \mathrm{E}+00$ & -0.2265 \\
\hline 10 & 95010 & $2.571980 \mathrm{E}+00$ & $4.974188 \mathrm{E}+00$ & $6.987900 \mathrm{E}+00$ & $7.021002 \mathrm{E}+00$ & 0.4737 \\
\hline 11 & 95011 & $2.571980 \mathrm{E}+00$ & $5.497787 \mathrm{E}+00$ & $6.326850 \mathrm{E}+00$ & $6.367450 \mathrm{E}+00$ & 0.6417 \\
\hline 12 & 95012 & $2.571980 \mathrm{E}+00$ & $6.021385 \mathrm{E}+00$ & $6.290680 \mathrm{E}+00$ & $6.121809 \mathrm{E}+00$ & -2.6845 \\
\hline 13 & 95013 & $3.709440 \mathrm{E}+00$ & $2.617993 \mathrm{E}-01$ & $5.840500 \mathrm{E}+00$ & $5.775884 \mathrm{E}+00$ & -1.1063 \\
\hline 14 & 95014 & $3.709440 \mathrm{E}+00$ & $7.853980 \mathrm{E}-01$ & $6.119200 \mathrm{E}+00$ & $6.235790 \mathrm{E}+00$ & 1.9053 \\
\hline 15 & 95015 & $3.709440 \mathrm{E}+00$ & $1.308997 \mathrm{E}+00$ & $7.383570 \mathrm{E}+00$ & $7.241512 \mathrm{E}+00$ & -1.9240 \\
\hline 16 & 95016 & $3.709440 \mathrm{E}+00$ & $1.832595 \mathrm{E}+00$ & $8.743020 \mathrm{E}+00$ & $8.791854 \mathrm{E}+00$ & 0.5585 \\
\hline 17 & 95017 & $3.709440 \mathrm{E}+00$ & $2.356194 \mathrm{E}+00$ & $1.059640 \mathrm{E}+01$ & $1.058257 \mathrm{E}+01$ & -0.1305 \\
\hline 18 & 95018 & $3.709440 \mathrm{E}+00$ & $2.879793 \mathrm{E}+00$ & $1.196610 \mathrm{E}+01$ & $1.189394 \mathrm{E}+01$ & -0.6030 \\
\hline 19 & 95019 & $3.709440 \mathrm{E}+00$ & $3.403392 \mathrm{E}+00$ & $1.202880 \mathrm{E}+01$ & $1.198541 \mathrm{E}+01$ & -0.3607 \\
\hline 20 & 95020 & $3.709440 \mathrm{E}+00$ & $3.926991 \mathrm{E}+00$ & $1.075220 \mathrm{E}+01$ & $1.074345 \mathrm{E}+01$ & -0.0814 \\
\hline 21 & 95021 & $3.709440 \mathrm{E}+00$ & $4.450589 \mathrm{E}+00$ & $8.753530 \mathrm{E}+00$ & $8.816588 \mathrm{E}+00$ & 0.7204 \\
\hline 22 & 95022 & $3.709440 \mathrm{E}+00$ & $4.974188 \mathrm{E}+00$ & $7.140310 \mathrm{E}+00$ & $7.110672 \mathrm{E}+00$ & -0.4151 \\
\hline 23 & 95023 & $3.709440 \mathrm{E}+00$ & $5.497787 \mathrm{E}+00$ & $6.004880 \mathrm{E}+00$ & $6.118496 \mathrm{E}+00$ & 1.8921 \\
\hline 24 & 95024 & $3.709440 \mathrm{E}+00$ & $6.021385 \mathrm{E}+00$ & $5.712410 \mathrm{E}+00$ & $5.744753 \mathrm{E}+00$ & 0.5662 \\
\hline 25 & 95025 & $4.398025 \mathrm{E}+00$ & $2.617993 \mathrm{E}-01$ & $5.552110 \mathrm{E}+00$ & $5.574821 \mathrm{E}+00$ & 0.4091 \\
\hline 26 & 95026 & $4.398025 E+00$ & $7.853980 \mathrm{E}-01$ & $6.154290 \mathrm{E}+00$ & $6.098397 \mathrm{E}+00$ & -0.9082 \\
\hline 27 & 95027 & $4.398025 \mathrm{E}+00$ & $1.308997 \mathrm{E}+00$ & $7.282590 \mathrm{E}+00$ & $7.326494 \mathrm{E}+00$ & 0.6029 \\
\hline 28 & 95028 & $4.398025 \mathrm{E}+00$ & $1.832595 \mathrm{E}+00$ & $9.252290 \mathrm{E}+00$ & $9.273912 \mathrm{E}+00$ & 0.2337 \\
\hline 29 & 95029 & $4.398025 \mathrm{E}+00$ & $2.356194 \mathrm{E}+00$ & $1.160550 \mathrm{E}+01$ & $1.158610 \mathrm{E}+01$ & -0.1671 \\
\hline 30 & 95030 & $4.398025 \mathrm{E}+00$ & $2.879793 \mathrm{E}+00$ & $1.331850 \mathrm{E}+01$ & $1.334069 \mathrm{E}+01$ & 0.1666 \\
\hline 31 & 95031 & $4.398025 \mathrm{E}+00$ & $3.403392 \mathrm{E}+00$ & $1.347080 \mathrm{E}+01$ & $1.352807 \mathrm{E}+01$ & 0.4252 \\
\hline 32 & 95032 & $4.398025 \mathrm{E}+00$ & $3.926991 \mathrm{E}+00$ & $1.201480 \mathrm{E}+01$ & $1.195594 \mathrm{E}+01$ & -0.4899 \\
\hline 33 & 95033 & $4.398025 \mathrm{E}+00$ & $4.450589 \mathrm{E}+00$ & $9.411220 \mathrm{E}+00$ & $9.480652 \mathrm{E}+00$ & 0.7378 \\
\hline 34 & 95034 & $4.398025 \mathrm{E}+00$ & $4.974188 \mathrm{E}+00$ & $7.393840 \mathrm{E}+00$ & $7.311419 \mathrm{E}+00$ & -1.1147 \\
\hline 35 & 95035 & $4.398025 \mathrm{E}+00$ & $5.497787 \mathrm{E}+00$ & $6.088130 \mathrm{E}+00$ & $6.070963 \mathrm{E}+00$ & -0.2820 \\
\hline 36 & 95036 & $4.398025 \mathrm{E}+00$ & $6.021385 \mathrm{E}+00$ & $5.590140 \mathrm{E}+00$ & $5.586743 \mathrm{E}+00$ & -0.0608 \\
\hline
\end{tabular}

Fitting function:

$$
\begin{aligned}
\mathrm{F}(\mathrm{r}, \theta)= & 7.903271-7.093754 \mathrm{E}-1 \mathrm{r} \cos (\theta)+5.345234 \mathrm{E}-2 \mathrm{r} \sin (\theta)-3.823238 \mathrm{E}-3 \mathrm{r} \sin (\theta) \cos (\theta) \\
& +2.669236 \mathrm{E}-2 \mathrm{r}^{2} \cos (2 \theta)+5.569351 \mathrm{E}-3 \mathrm{r}^{2} \sin (2 \theta)-6.917868 \mathrm{E}-4 \mathrm{r}^{2} \sin (2 \theta) \cos (2 \theta) \\
& -3.651311 \mathrm{E}-1 \mathrm{r}+1.359917 \mathrm{E}-1 \mathrm{r}^{2}+3.481487 \mathrm{E}-2 \mathrm{r} \cos (2 \theta)-1.119501 \mathrm{E}-2 \mathrm{r}^{3} \cos (\theta) \cos (2 \theta) \\
& -4.186508 \mathrm{E}-3 \mathrm{r}^{3} \cos (\theta) \sin (2 \theta)+3.216629 \mathrm{E}-3 \mathrm{r}^{3} \sin (\theta) \cos (2 \theta) \\
& -1.059137 \mathrm{E}-2 \mathrm{r}^{3} \sin (\theta) \sin (2 \theta)
\end{aligned}
$$

The angle, $\theta$, is measured in radians, and the radius, $r$, has units of centimeters. 


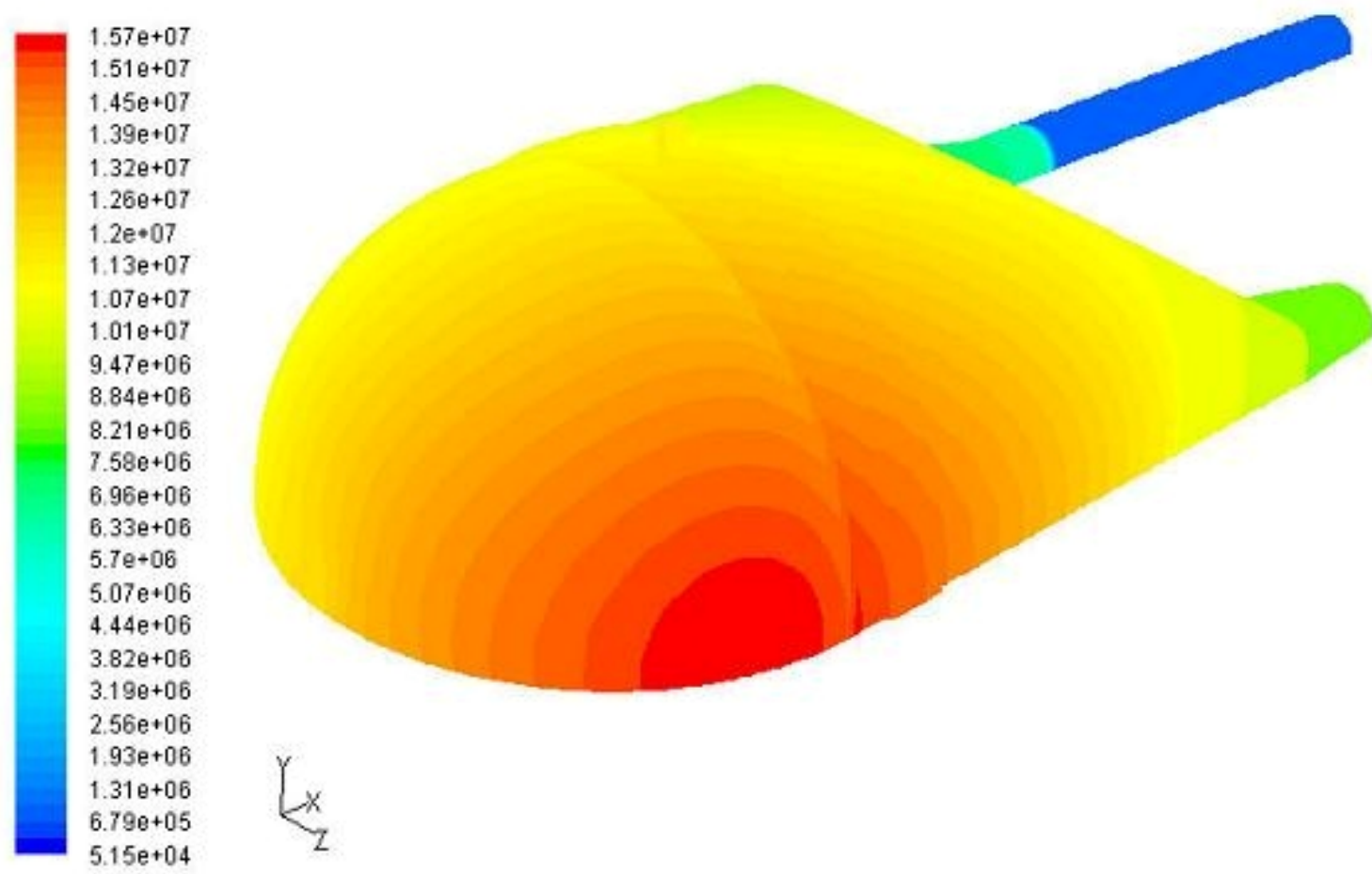

Fig. 6. Three-dimensional heating distribution for the HFIR HB4 cold source vessel. (The units are watts per cubic meter). 


\section{SHIELDING}

The HB4 beam tube has four guides that direct the cold-neutron beam to the various instruments. Initially, the four guides are together in a common casing, and three of the guides are routed through a second common casing. The common casings are rather complicated geometrically but are modeled in MCNP as steel boxes. The material regions that are not modeled could have two effects: (1) they could scatter more radiation toward the shields, and/or (2) they could partially shield radiation directed toward the shields. Whether the modeled geometry yields conservative results is not readily known. The beams are shielded by the concrete floor, the east and west side shields, and a top or roof shield. The shielding extends from the reactor's biological shield, through a beam room and a transition building, and then terminates in the guide hall. Places where the shielding joins existing structures are of concern because the imperfect mating of the two surfaces leaves gaps that allow radiation to stream outward, resulting in higher dose rates at those locations.

The shielding calculations used equivalent point sources at various locations along the axis of HB4 to simulate the reactor source, equivalence having been demonstrated by MCNP calculations.

Two-dimensional and three-dimensional models of the beam tube were developed; the three-dimensional one was modeled using the combinatorial geometry software from the MORSE Monte Carlo code package. ${ }^{6}$ For each $(\mathrm{R}, \mathrm{Z})$ mesh in the two-dimensional geometry, a ring of points at equally spaced azimuths was calculated. Uncollided fluxes and first-collision source moments were calculated and averaged over the ring. A DORT ${ }^{7}$ calculation was performed using the two-dimensional model, the first-collision source, a very fine directional quadrature, the VELM61 cross-section library, ${ }^{8}$ and a $\mathrm{P}_{5}$ Legendre polynomial expansion of the scattering cross sections. A boundary flux file was written for a plane near the center of the shutter. It was felt that any structures added beyond the shutter would not cause significant changes to the source at the plane. Uncollided fluxes were added to the directional fluxes and cumulative distributions were created for source sampling by a user-written source subroutine for the MCNP4C code. ${ }^{9}$ The output data file had a binary format and was therefore specific to a particular computer. Angular dependence was limited to the polar angle. The plane source described above served as the basis for all Monte Carlo and coupled Monte Carlo/discrete ordinates shielding calculations for the HB4 shield tunnel.

\subsection{BULK SHIELDING}

Plan views of the HB4 beam tube and shield tunnel are given in Figs. 7 and 8 . Figure 7 shows the three regions that the beams pass through: (1) a beam room, (2) a transition building, and (3) a guide hall. Figure 8 shows a portion of the beam room, including the east (cold guide number 1, or CG1) and west (cold guide number 4, or CG4) side shields and major components involved in the shielding analyses. The general shielding thicknesses for the guides were determined without regard for any penetrations through the shields. The initially estimated shielding requirement for the walls and roof shield was $81.28 \mathrm{~cm}$ (32.0 in.) of a high-density concrete. The final shielding material is a hematite concrete, and the dose limit is $1 \mathrm{mrem} / \mathrm{h}$ on contact. Because the hematite concrete is a better shielding material than the original high-density concrete, the shield thicknesses in the beam room were scaled back to $71.12 \mathrm{~cm}$ ( 28.0 in.) for the west wall and $60.96 \mathrm{~cm}$ (24.0 in.) for the roof. For the east wall, the first portion of the wall that mated with the biological shield remained at $81.28 \mathrm{~cm}$, while the second part was trimmed to $71.12 \mathrm{~cm}$. In the transition building, the walls and roof are composed of ordinary $60.96-\mathrm{cm}$-thick concrete. An MCNP4C calculation was run using the plane source described above. Surface sources were written for the interior roof and side surfaces of the shield tunnel, and DORT X-Y calculations were performed using boundary sources created from the MCNP4C data by binning the data over X and $\mathrm{Y}$ mesh and averaging the data over the transverse dimension. The calculations were performed assuming 


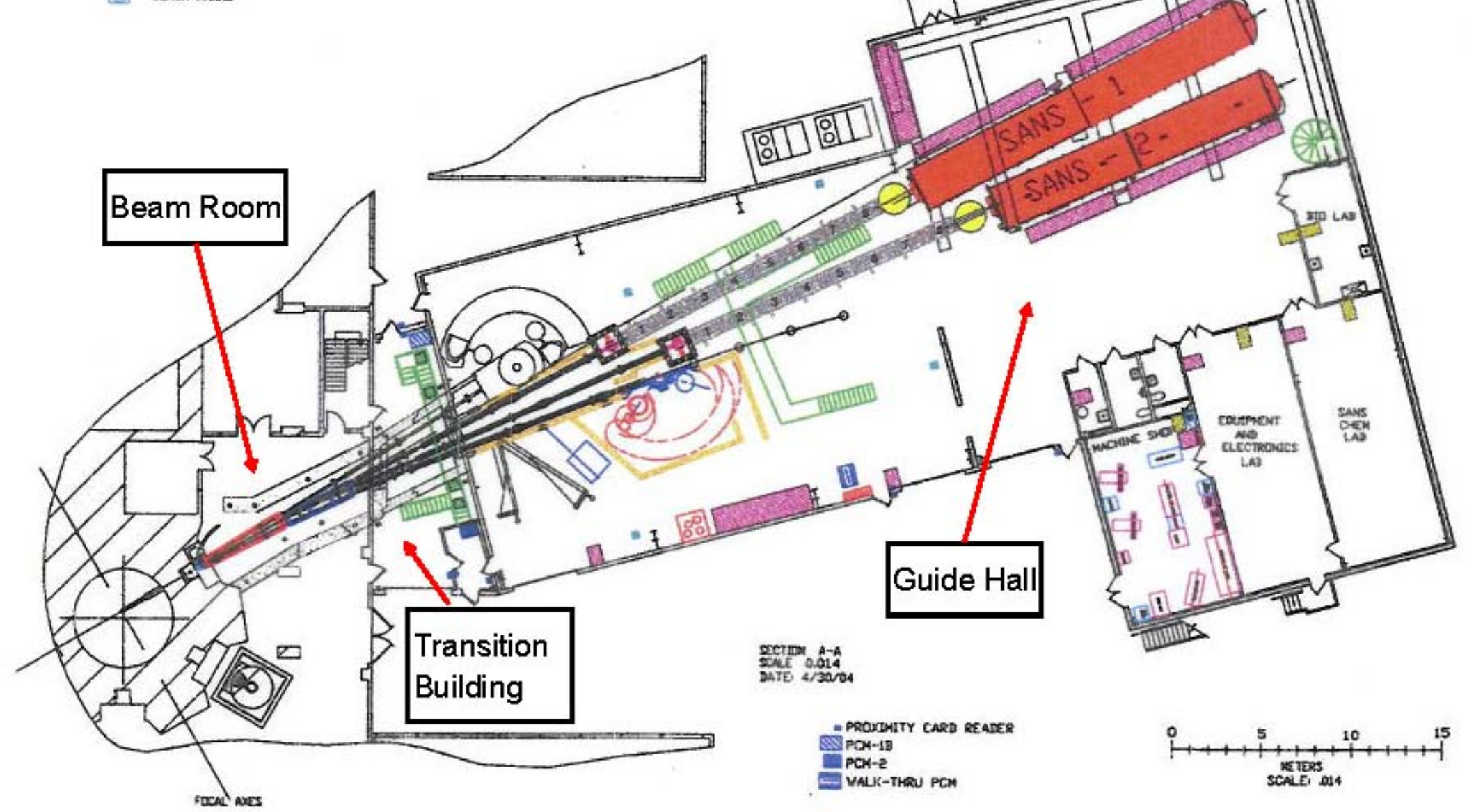

Fig. 7. Plan view of the HFIR HB4 beam tube shielding, experiment stations, and structures. 


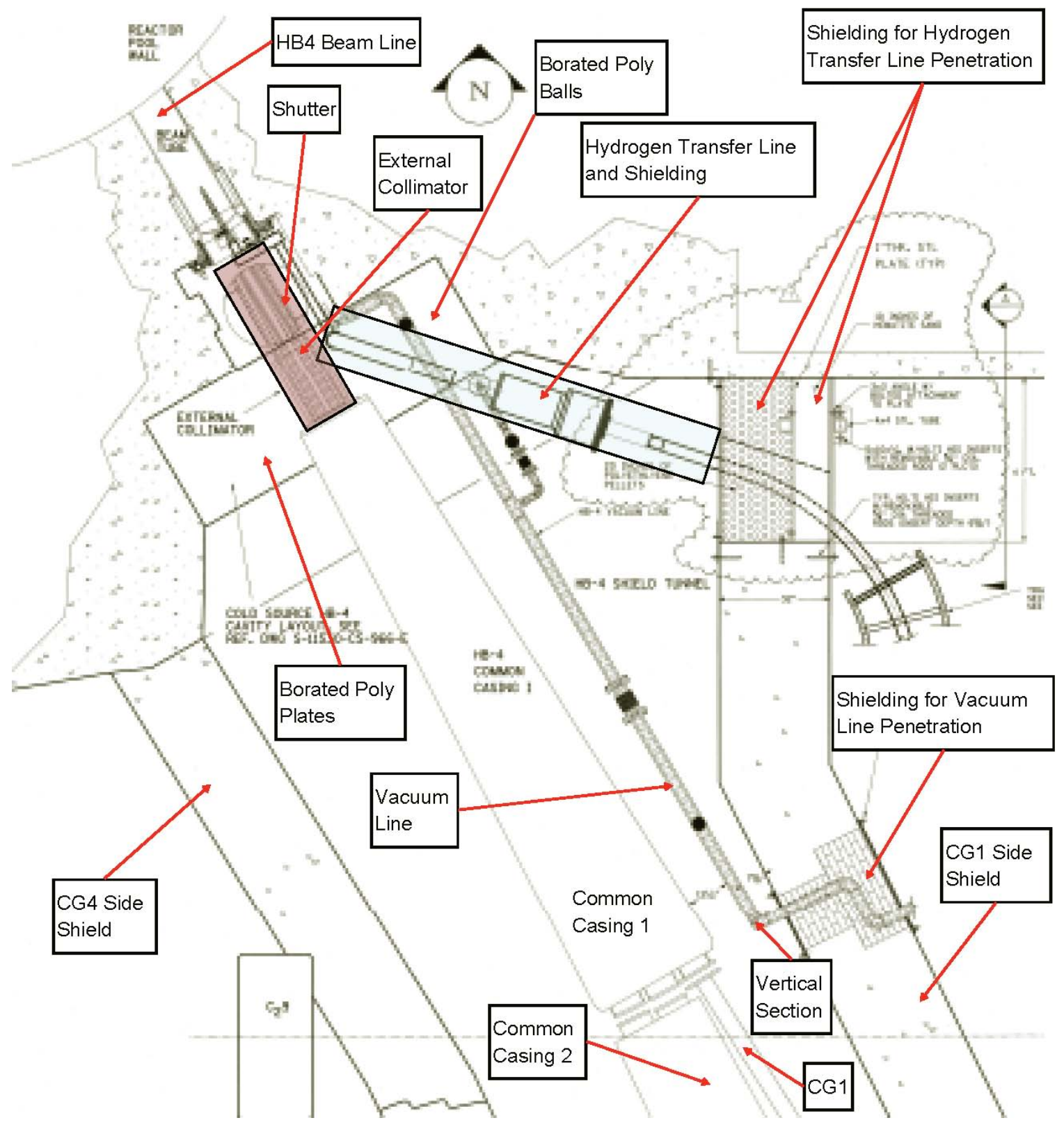

Fig. 8. Plan view of the HFIR HB4 beam tube shielding and components within the beam room. 
that the shields were $81.28 \mathrm{~cm}$ thick. Neutron, photon, and total dose-rate contours were plotted throughout the roof and side shield mockups, and maximum and average dose rates were calculated from flux traverses at the appropriate shield depths. The calculated dose rates were then scaled by results from west side wall calculations for shield thicknesses of $81.28,71.12$, and $60.96 \mathrm{~cm}$ because the calculated dose rates at points inside a shield would be elevated due to backscattering from the material beyond the thickness of interest. The adjusted calculated maximum dose rates for the east wall are 0.14 and $0.81 \mathrm{mrem} / \mathrm{h}$ for neutrons and photons, respectively. The adjusted maximum calculated dose rates for the west wall are $0.051 \mathrm{mrem} / \mathrm{h}$ neutron and $0.46 \mathrm{mrem} / \mathrm{h}$ photon. Adjusted maximum calculated dose rates for the roof are $0.70 \mathrm{mrem} / \mathrm{h}$ neutron and $2.54 \mathrm{mrem} / \mathrm{h}$ photon. The adjusted calculated average neutron dose rates are $0.085,0.38$, and $0.037 \mathrm{mrem} / \mathrm{h}$ for the east side, the roof, and the west side shields, respectively. The respective calculated average photon dose rates are $0.51,1.09$, and $0.29 \mathrm{mrem} / \mathrm{h}$. Calculated results are compared with measured results in Table 5.

Table 5. Comparison of calculated and measured neutron and photon contact dose rates (in millirems per hour) for the HFIR HB4 shield tunnel

\begin{tabular}{|c|c|c|c|c|c|c|}
\hline \multirow{2}{*}{ Measurement location } & \multicolumn{3}{|c|}{ Neutron dose rate } & \multicolumn{3}{|c|}{ Photon dose rate } \\
\hline & Calculated & Measured & $\mathbf{C} / \mathbf{M}$ & Calculated & Measured & $\mathbf{C} / \mathbf{M}$ \\
\hline \multicolumn{7}{|l|}{ Beam room } \\
\hline General east shield wall & 0.085 & $<0.1$ & $>0.85$ & 0.51 & 0.3 & 1.7 \\
\hline General west shield wall & 0.037 & $<0.1$ & $>0.37$ & 0.29 & 0.4 & 0.73 \\
\hline General roof area & 0.38 & $<0.1$ & $>3.8$ & 1.09 & 0.5 & 2.2 \\
\hline $\begin{array}{l}\text { East shield wall interface } \\
\text { with biological shield }\end{array}$ & 2.5 & 1.4 & 1.79 & 3.8 & 2.0 & 1.9 \\
\hline $\begin{array}{l}\text { West shield wall } \\
\text { interface with } \\
\text { biological shield }\end{array}$ & 1.0 & 5.0 & 0.2 & 3.0 & 24.0 & 0.13 \\
\hline $\begin{array}{l}\text { Roof interface with } \\
\text { biological shield }\end{array}$ & 0.7 & 1.5 & 0.47 & 2.54 & 3.0 & 0.85 \\
\hline Subpile room at railing & 3.8 & 4.0 & 0.95 & 2.5 & 4.0 & 0.63 \\
\hline $\begin{array}{l}\text { Hydrogen line shield } \\
\text { penetration }\end{array}$ & 0.47 & 2.0 & 0.24 & 7.15 & 6.0 & 1.19 \\
\hline $\begin{array}{l}\text { Vacuum line shield } \\
\text { penetration }\end{array}$ & $\begin{array}{l}6.57^{a} \\
51.7^{b} \\
\end{array}$ & 2.0 & $\begin{array}{r}3.3 \\
26.0 \\
\end{array}$ & $\begin{array}{l}1.21^{a} \\
6.69^{b}\end{array}$ & 0.6 & $\begin{array}{r}2.0 \\
11.2 \\
\end{array}$ \\
\hline \multicolumn{7}{|l|}{ Transition building } \\
\hline General roof area & $3.8 \times 10^{-6}$ & $<0.1$ & $>3.8 \times 10^{-5}$ & $1.3 \times 10^{-5}$ & 0.5 & $2.6 \times 10^{-5}$ \\
\hline Roof at entrance & 0.0024 & $<0.1$ & $>0.024$ & 0.84 & 0.5 & 1.68 \\
\hline $\begin{array}{l}\text { West shield wall at } \\
\text { entrance }\end{array}$ & 0.0019 & $<0.1$ & $>0.019$ & 0.29 & 0.4 & 0.73 \\
\hline \multicolumn{7}{|l|}{ Guide hall } \\
\hline $\begin{array}{l}\text { CG2 velocity selector } \\
\text { shield }\end{array}$ & 0.003 & Small & - & 0.1 & Small & - \\
\hline $\begin{array}{l}\text { CG3 velocity selector } \\
\text { shield }\end{array}$ & 0.0003 & Small & - & 0.03 & Small & - \\
\hline
\end{tabular}

For measurements made away from penetrations, the measured dose rates were listed as $<0.1 \mathrm{mrem} / \mathrm{h}$ for neutrons and 0.3 (east wall) and 0.4 (west wall) $\mathrm{mrem} / \mathrm{h}$ for photons. For the roof, the measured dose rates were $<0.1 \mathrm{mrem} / \mathrm{h}$ neutron and $0.5 \mathrm{mrem} / \mathrm{h}$ photon. Thus, except for the roof, measurements and calculations agree and indicate that the neutron dose rates are generally $0.1 \mathrm{mrem} / \mathrm{h}$ or less. The measured 
photon dose rates are 0.20 to 0.87 times the maximum calculated values and 0.46 to 1.38 times the average calculated values.

One would expect the DORT results to be lower than the measured results since the DORT results represent averages over the transverse dimension. The sources for the DORT calculations were averaged over the central 60-cm (23.6-in.) span of the transverse dimension. MCNP-calculated dose rates within the tunnel at points about $9 \mathrm{~m}(29.5 \mathrm{ft})$ from the core center and $61 \mathrm{~cm}(24.0 \mathrm{in}$.) above and below the guide level differed by factors of 1.6 to 2.1 (neutron) and 1.7 to 2.4 (photon) from the dose rates at guide level. Based on these results, one would find using simple integration procedures that the averaged source would be a factor of 1.3 below the value at guide level, and one would expect the calculated dose rate to be at most a factor of 1.3 less than the measured dose rate. Except for the average photon dose rate outside the west wall, all calculated dose rates for walls in the beam room were greater than the measured values. Measured dose rates at the west shield interface with the biological shield were much higher than the calculated values. The measured values for the west side shield interface were factors of 98 and 52 higher for neutrons and photons, respectively. At the east side wall interface, measurements were higher by a factor of 10 for neutrons and 2.5 for photons. For the roof interface, the measurements were higher only by factors of 2.1 and 1.4 for neutrons and photons, respectively. The calculations assume a tight fit between the tunnel shield and the biological shield. However, the real shield configuration might include a gap that is not modeled. Visual inspection indicated tight fits all around the shield; consequently, there may be other reasons for the measured high dose rates at the shield interface.

\subsection{SHIELD PENETRATIONS}

The hydrogen transfer and vacuum lines pass from the HB4 tunnel through the east shield wall to equipment used to circulate the coolant or to evacuate desired regions. Two rectangular holes were left in the bulk concrete shield. After the lines were passed through the shield wall, steel plates were placed on each side of the shield wall to enclose the rectangular holes and the space around each line was filled with compactable shield materials [such as hematite sand $\left(2.5 \mathrm{~g} / \mathrm{cm}^{3}\right)$ and borated polyethylene balls $\left.\left(0.475 \mathrm{~g} / \mathrm{cm}^{3}\right)\right]$ to reduce radiation transmission through the shield. Plots of the MCNP geometry for the hydrogen transfer line are shown in Figs. 9 and 10. In actuality, the paths of the tubes through the shield are curved to lessen radiation streaming effects, but the tubes were modeled as straight cylinders for simplicity. The hydrogen transfer line calculation was performed with MCNP using an MCNP boundary source file at the inner surface of the shield. The vacuum line calculation was performed using DORT and two X-Y geometric models and a boundary flux file created from MCNP leakages into the shield wall. The first geometric model assumed a homogeneous reduced-density material occupying a stepped rectangular region through which the vacuum line passes. The second model included a zigzag streaming path through the region, since a uniform filling of the region could not be ensured. The measured dose rates for the hydrogen transfer line were $2.0 \mathrm{mrem} / \mathrm{h}$ neutron and $6.0 \mathrm{mrem} / \mathrm{h}$ photon (Table 5 ). These dose rates are well above the general bulk shield dose rates. The maximum calculated dose rates for the hydrogen transfer line were $0.47 \mathrm{mrem} / \mathrm{h}$ neutron and $7.15 \mathrm{mrem} / \mathrm{h}$ photon. The neutron dose rate is underpredicted by a factor of 4.3 , but the photon dose rate is overpredicted by a factor of 1.19 , which qualifies as good agreement with the photon measurement. The maximum measured values of the dose for the vacuum line were $2.0 \mathrm{mrem} / \mathrm{h}$ neutron and $0.6 \mathrm{mrem} / \mathrm{h}$ photon. For the simplest geometry, the maximum calculated dose rates were $6.57 \mathrm{mrem} / \mathrm{h}$ neutron and $1.21 \mathrm{mrem} / \mathrm{h}$ photon, overpredicting the measured dose rates by factors of 2.0 to 3.3. The maximum dose rates for the conservative model were $51.7 \mathrm{mrem} / \mathrm{h}$ neutron and $6.69 \mathrm{mrem} / \mathrm{h}$ photon, overpredicting the measured dose rates by factors of 11.2 to 25.9. Actually, the boundary flux was conservative since it was based on a section of the wall closer to the reactor. While the actual flux levels at the vacuum line exit may be higher because of a "fanning" out of the beam with distance, the angles of incidence on the shield are shallower than at the close-in location 


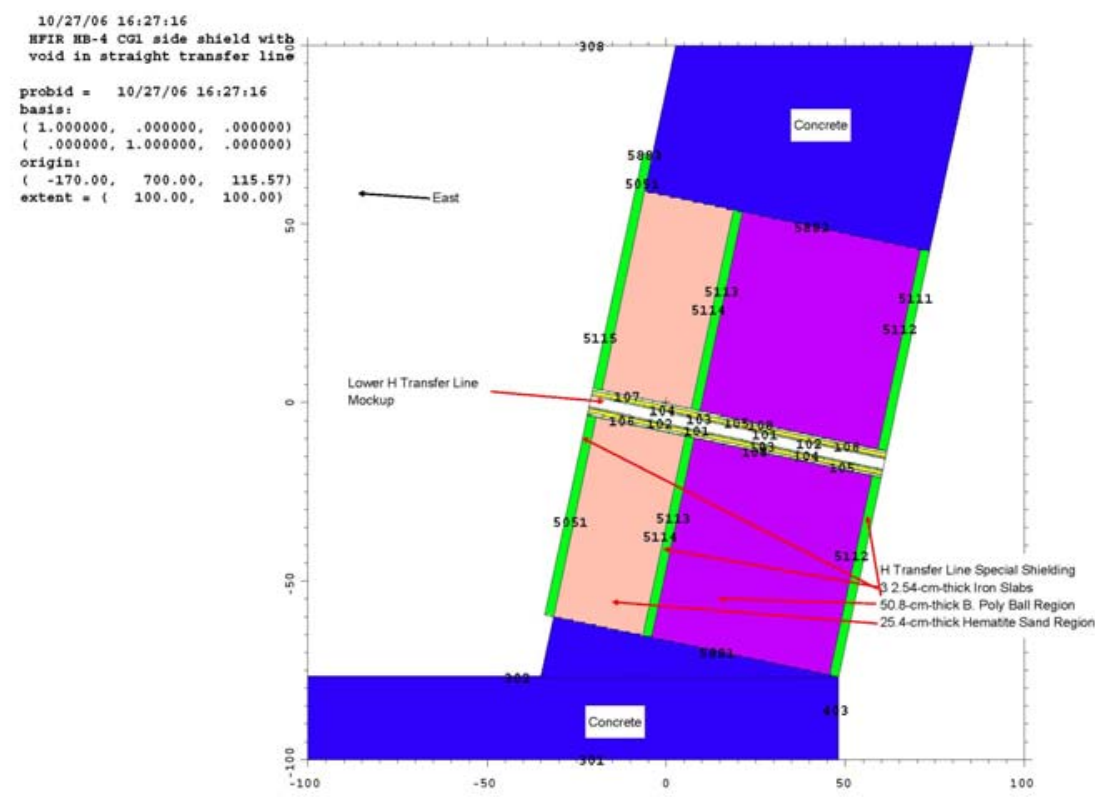

Fig. 9. Plan view of the MCNP geometry for the hydrogen transfer line in the east shield wall.

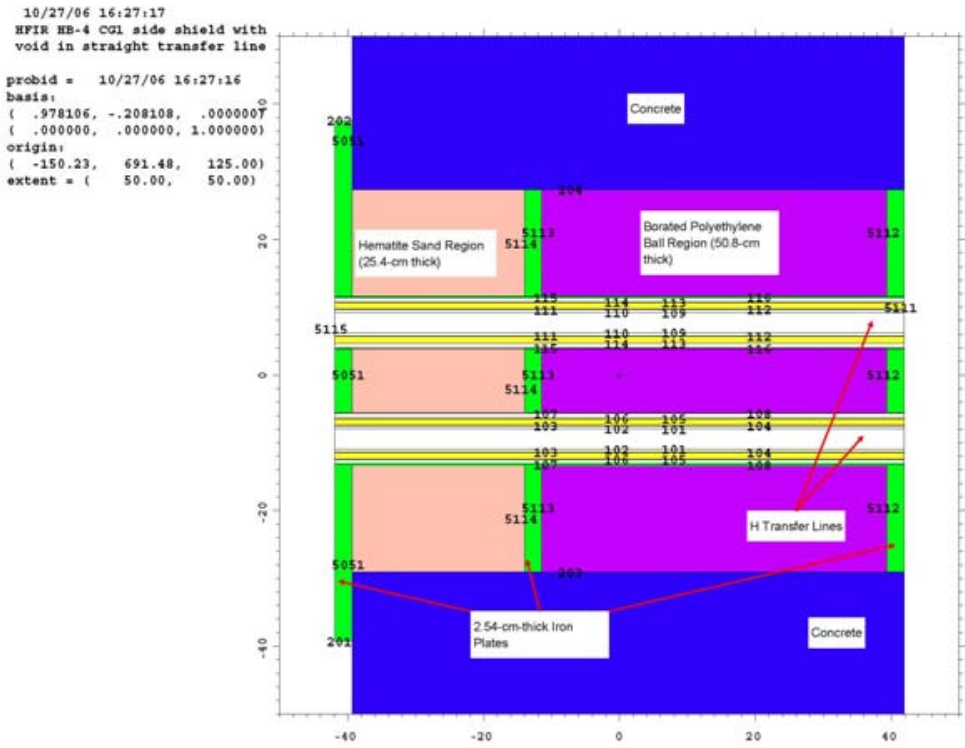

Fig. 10. Elevation view of the MCNP geometry for the hydrogen transfer line in the east shield wall.

where the shield is slanted inward rather than outward as it is at the vacuum line exit (see Fig. 8). There should be much less overprediction if MCNP leakages at the vacuum line exit are used.

Where the beam room shield tunnel meets the wall for the transition building, there existed a hollow wall separating two shield sections. MCNP calculations showed the dose rates around this area to be high. Therefore, a flowable concrete fill material was proposed for placement in the hollow region and a new calculation was performed. The calculated neutron dose rates are insignificant $(0.0024 \mathrm{mrem} / \mathrm{h}$ upon the roof and $0.0019 \mathrm{mrem} / \mathrm{h}$ on the side). The calculated photon dose rates are $0.84 \mathrm{mrem} / \mathrm{h}$ upon the roof 
and $0.29 \mathrm{mrem} / \mathrm{h}$ on the west side. The calculated roof dose rate is 1.68 times the general dose rate for the roof, and the measured value for the side is 1.38 times the calculated value. While the calculation used a material different from that used in the shield design, measurements and calculations still agreed within a factor of 2.

Shielding was also evaluated for velocity selectors at the ends of the two central cold guides (CG2 and CG3). Cold neutrons incident on the selector blades are absorbed by the blades (which contain $\mathrm{Gd}_{2} \mathrm{O}_{3}$ ), producing mostly $1-5-\mathrm{MeV}$ photons, leading to a requirement for shielding. Shield walls around the blade were joined together in steps to prevent streaming. Near-normal cold-neutron beams were modeled in DORT X-Y and R-Z input files, and the calculations were performed. Because of the X-Y geometry being infinite in one dimension, the $X-Y$ results were not properly normalized. The dose rates from the $\mathrm{X}-\mathrm{Y}$ calculation were about 30 times those from the R-Z calculation. Therefore, the $\mathrm{X}-\mathrm{Y}$ dose rates were divided by 30 , leaving the maximum $0.01-\mathrm{mrem} / \mathrm{h}$ surface dose rate. The measurements showed "nothing of significance." This measurement is qualitatively in agreement with the calculations since the neutron doses of 0.003 and $0.0003 \mathrm{mrem} / \mathrm{h}$ are not significant and the photon dose rates of 0.03 and $0.1 \mathrm{mrem} / \mathrm{h}$ are generally not of concern. No absolute measured dose rate less than $0.1 \mathrm{mrem} / \mathrm{h}$ was reported. 



\section{CONCLUSIONS}

Shielding and heating analyses for the HFIR HB4 beam tube have been performed. The heating analyses were performed with the MCNP5 code and a modification thereof, and the shielding analyses were performed using a special version of the MCNP4C code coupled to the DORT 2-D radiation transport code. Heating within the cold source was measured, and many dose measurements were made for the shielding surrounding the HB4 neutron guides. The calculated heating rates were in very good agreement with the measurements. Except for measured results at shield interfaces or near penetrations, calculated dose rates agreed with measurements within a factor of 2 or they, like the measurements, indicated very small values (which was also the case for most neutron measurements and many photon measurements). While some measured and calculated neutron and photon dose rates agreed within a factor of 2, improved agreement could possibly be achieved with more detailed modeling of components within the shield tunnel. Shield interfaces may not be modeled accurately, particularly where shields are moveable to allow access to the tunnel. Any resultant gap could result in radiation streaming and higher dose rates at the interface. 



\section{REFERENCES}

1. X-5 Monte Carlo Team, MCNP-A General Monte Carlo N-Particle Transport Code, Version 5, Vols. I, II, and III, LA-UR-03-1987, LA-CP-03-0245, and LA-CP-03-0284, Los Alamos National Laboratory, Los Alamos, N.M.

2. D. R. Vondy, T. B. Fowler, and G. W. Cunningham, The Bold Venture Computation System for Nuclear Core Analysis, Version III, ORNL-5711, Oak Ridge National Laboratory, Oak Ridge, Tenn., June 1981.

3. J. A. Bucholz, Source Terms for HFIR Beam Tube Shielding Analyses, and a Complete Shielding Analysis of the HB-3 Tube, ORNL/TM-13720, Oak Ridge National Laboratory, Oak Ridge, Tenn., July 2000.

4. M. Sami and W. Wangard (Fluent, Inc.), Best Estimate Heat Transfer Analysis of the HFIR HB-4 Cold Source Moderator Vessel Using FLUENT, C-HFIR-2005-228, Rev. 0, December 8, 2005.

5. E. Popov, "Independent Review of the Report Best Estimate Heat Transfer Analysis of the HFIR HB-4 Cold Source Moderator Vessel Using FLUENT," C-HFIR-2005-228-IR, July 21, 2006.

6. M. B. Emmett, The MORSE Monte Carlo Radiation Transport Code System, ORNL-4972/R1, Oak Ridge National Laboratory, Oak Ridge, Tenn., February 1983.

7. W. A. Rhoades and R. L. Childs, "The DORT Two-Dimensional Discrete Ordinates Code," Nucl. Sci. Eng. 99, 88-89 (1988).

8. C. Y. Fu and D. T. Ingersoll, VELM61 and VELM22: Multigroup Cross-Section Libraries for Sodium-Cooled Reactor Shield Analysis, ORNL/TM-10302, Oak Ridge National Laboratory, Oak Ridge, Tenn., April 1987.

9. J. F. Briesmeister, ed., MCNP-A General Monte Carlo N-Particle Transport Code, Version 4C, LA-13709-M, Los Alamos National Laboratory, Los Alamos, N.M., April 2000. 



\section{ORNL/TM-2009/012}

\section{INTERNAL DISTRIBUTION}

1. C. W. Alexander, 7920, MS-6384

2. E. D. Blakeman, 5700, MS-6170

3. S. E. Burnette, 7917, MS-6398

4. D. H. Cook, 7917, MS-6399

5. R. A. Crone, 7917, MS-6398

6. M. B. Farrar, 7917, MS-6398

7. P. D. Ferguson, 8600, MS-6466

8. J. D. Freels, 7964C, MS-6392

9. F. X. Gallmeier, 8600, MS-6466

10. D. R. Hamrin, 5300, MS-6254

11. G. J. Hirtz, 7918, MS-6423

12. R. W. Hobbs, 7918, MS-6423

13. J. O. Johnson, 5700, MS-6170

14. T. M. Miller, 5700, MS-6170

15. C. V. Parks, 5700, MS-6170
16. D. E. Peplow, 5700, MS-6170

17. E. L. Popov, 5700, MS-6167

18. R. T. Primm III, 7917, MS-6399

19. I. Remec, 5700, MS-6170

20. J. E. Rushton, 5700, MS-6152

21-22. D. L. Selby, 8600, MS-6476

23-25. C. O. Slater, 5700, MS-6170

26. K. A. Smith, 7917, MS-6398

27. J. C. Wagner, 5700, MS-6170

28. Central Research Library, 4500 N, MS-6208

29. RRD Document Control Center, 7917, MS-6399

30. Return extra ORNL copies to: D. J. Weaver, 5700, MS-6170

\section{EXTERNAL DISTRIBUTION}

31. J. A. Bucholz, 117 Cahill Lane, Oak Ridge, TN 37830

32. R. D. Cheverton, 2703 West Gallaher Ferry Road, Knoxville, TN 37923

33. J. C. McKibben, University of Missouri Research Reactor Facility, Columbia, MO 65211

34. G. J. Malosh, U.S. Department of Energy, SC-3/Forrestal Building, 1000 Independence Ave., S.W., Washington, DC 20585

35. J. O. Moore, ORNL Site Office, Department of Energy, P.O. Box 2008, Oak Ridge, TN 37831-6269

36. T. Newton, MIT Nuclear Reactor Laboratory, 138 Albany Street, Cambridge, MA 02139

37. R. D. Rothrock, 705 Cordova Lane, Lenoir City, TN 37771

38. R. E. Williams, NIST Center for Neutron Research, 100 Bureau Drive, Stop 8560, Gaithersburg, MD 20899 
